\title{
Comparative analysis of structure and texture of industrial coke
}

\author{
(C) Sergey A. Sozinov, Anna N. Popova,${ }^{{ }^{+}}$and Yulia N. Dudnikova \\ Federal Research Center on Coal and Coal Chemistry. Siberian Branch, Russian Academy \\ of Sciences. Sovetsky Ave., 18. Kemerovo,650000.Russia.E-mail: h991@yandex.ru
}

\begin{abstract}
*Supervising author; ${ }^{+}$Corresponding author
Keywords: coke, X-ray diffraction, X-ray structural analysis, analytical scanning electron microscopy, adsorption porosimetry.
\end{abstract}

\section{Abstract}

In this work, industrial samples of coke from two different manufacturers were studied using a complex of structural methods: phase and structural analysis by powder X-ray diffraction, analytical scanning electron microscopy and adsorption porosimetry. The main structural parameters (longitudinal and transverse dimensions of packets and lamellas that fit into packets) and textural characteristics (specific surface area, pore space structure) of the studied samples of industrial coke were determined, and an analysis of the features of their microstructure was made. The results obtained in this work make it possible to unambiguously divide the studied cokes into 2 types: "anisotropic" and "isotropic". For anisotropic coke samples, the longitudinal size of the lamellas that fit into the packs is several times larger than the transverse size of these packets (La $>$ Lc), and this type of coke is characterized by a pronounced lamellar microstructure. Samples of "isotropic" cokes are characterized by comparable sizes of packets of lamellar layers in the longitudinal and transverse directions $(\mathrm{La} \approx \mathrm{Lc}$ ) and an amorphous microstructure. Because of the work, a complete relationship was revealed between the structural parameters, shape, morphology and texture characteristics of the particles of coke samples, as well as a sufficient correspondence between the data obtained by three independent methods. The consistency of the conclusions drawn from the results of the analysis of the data of the performed complex of physicochemical studies makes it possible to consider X-ray diffraction analysis in combination with analytical electron microscopy and adsorption porosimetry as the necessary complementary tools for assessing the main properties of cokes with a view to their possible use in various technological processes.

\section{References}

[1] M.W. Meier. Cracking Behavior of Anodes. PhD Thesis. Federal Institute of Technology (ETH). Zurich, Switzerland. 1996. 122p.

[2] M.M. Akhmetov, S.A. Zaitseva, R.N. Gimaev. Production and use of calcined needle coke. Moscow: TSNIITEneftekhim. 1983. 56p. (russian)

[3] P.X. Niu, Y.L. Wang, L. Zhan. Electrochemical Performance of Needle Coke and Pitch Coke Used as Anode Material for Li-ion Battery. J. Mater. Sci. Eng. 2011. No.29. P.204-209.

[4] S. Hume. Reactivity of the anode. Krasnoyarsk: Classic Center LLC. 2003. 457p. (russian)

[5] A. Sarkar E $\square$ ect of coke properties on anode properties. Doctor of philosophy thesis. University of Quebec at Chicoutimi. 2015.

[6] W.K. Fisher, R.C. Perruchoud. Influence of Coke Calcining Parameters on Petroleum Coke Quality. Light Metals. 1985. P.811-824.

[7] H.P. Halim, J.S. Im, C.W. Lee. Preparation of needle coke from petroleum by-products. CarbonLett. 2013. No.14(152).

[8] H. Predel. Petroleum coke. Bohnet M, ed. Ullmann's Encyclopedia of Industrial Chemistry. Wiley-VCH, Weinheim. 2012. 361p.

[9] Y. Cheng, Q. Zhang, Ch. Fang, Y. Ouyang, D. Liu. Co-Carbonization Behaviors of Petroleum Pitch. Waste SBS: Influence on Morphology and Structure of Resultant Cokes. J Anal Appl Pyrol. 2018. No.129. P.154164.

[10] E.V. Litvinov, A.F. Tovstenko. Influence of structural parameters of coke on the operational properties of anodic mass. VAMI Proceedings. 1983. P.43-48. (russian)

[11] T. Tano, T. Oyama, T. Oda, I. Fujinaga, H. Hashisaka. Pat. EP2336267 A1 European. Process for producing needle coke for graphite electrode and stock oil composition for use in the process. 2011. 
[12] Y.-M. Zhu, X.-F. Zhao, L.-J. Gao et al. Quantitative Study of the Microcrystal Structure on Coal Based on Needle Coke with Curve-Fitted of XRD and Raman Spectrum. Spectroscopy and Spectral Analysis. 2017. No.37. P.1919-1924.

[13] GOST 26132-84. Oil and pitch coke. Microstructure evaluation method. 1984. (russian)

[14] V.G. Zelenkin, N.P. Molotok. Graphite electrodes for high power electric steel furnaces. Moscow: TSNIItsvetmet economy and information. 1982. 48p. (russian)

[15] R.C. Perruchoud, M.W. Meier, W.K. Fischer. Coke Characteristics from the Refi ners to the Smelters. Light Metals. 2000. P.459-465.

[16] B. Vitchus, F. Cannova, H. Childs. Calcined Coke from Crude Oil to Customer Silo. Light Metals. 2001. P.589-596.

[17] S. Song, X. Cheng. The influence of alkyl group on needle coke formation. Adv. Mater. Res. 2011. Vol.335. P.1433-1438.

[18] M.M. Akhmetov. To the mechanism of formation of the structure of needle cokes. World of Oil Products. 2015. No.4. P.29-35. (russian)

[19] X.P. Zhou, D.Sh. Xu, P.X. Zhang et al. Research on coal tar pitch based needle coke production quality. Advanced materials research. 2013. Vol.711. P.155-160.

[20] B.A. Sadler, B.J. Welch. Anode Consumption Mechanisms - a Practical Review of the theory and Anode Property Consideration. Seventh Australasian Aluminium Smelting Technology Conference and Workshop. 2001. 41p.

[21] P.X. Niu, Y.L. Wang, L. Zhan. Electrochemical Performance of Needle Coke and Pitch Coke Used as Anode Material for Li-ion Battery. J. Mater. Sci. Eng. 2011. Vol.29. P.204-209.

[22] B. Zhang, H. Guo, X. Li et al. Mechanism for effects of structure and properties of carbon on its electrochemical characteristics as anode of lithium ion battery. J. Cent. South Univ. (Sci. Technol.). 2007. Vol.38. P.454-460.

[23] K. Hulse. Anode production. Krasnoyarsk: Classic Center LLC. 2004. 452p. (russian)

[24] D.F. Varfolameev, I.R. Khairudinov, M.M. Akhmetov et al. On the nature of sulfur in petroleum cokes. Solid Fuel Chemistry. 1984. No.4. P.128-132. (russian)

[25] ICDD, PDF-2 2011 (Database), edited by Dr. Surya Kalakkodu, International Centre for Diffraction Data, Newtown Square, PA, USA. 2011.

[26] A.N. Popova. Crystallographic analysis of graphite by x-ray diffraction. Coke and Chemistry. 2017. Vol.60. No.9. P.361-365. (russian)

[27] H. Shi, J.N. Reimers, J.R. Dahn. Structure-refinement program for disorderd carbon. J. Appl. Cryst. 1993. Vol.26. P.827-836.

[28] M. Inagaki, M. Shiraishi. The evaluation of graphitization degree. Carbon Tech. 1951. Vol.5. P.165-175.

[29] H.J. Wang, H.F. Wang. The effect of graphitization temperature on the microstructure and mechanical properties of carbon fibers. New Carbon Mater. 2005. Vol.20. P158-163.

[30] M. Chin. Effect of physical disturbance on the structure of needle coke. Phys. B. 2010. Vol.19(10). P.108101.

[31] I.C. Popovici, S. Birghila, G. Voicu, V. Ionescu, V. Ciupina, G. Prodan. Morphological and microstructural characterization of some petroleum cokes as potential anode materials in lithium ion batteries. $J$ Optoelectron Adv M. 2010. Vol.12(9). P.1903-1908.

[32] I.J. Kim, S. Yang, M.-J. Jeon, S.-I. Moon, H.-S. Kim, et al. Structures and electrochemical performances of pyrolized carbons from graphite oxides for electric double-layer capacitor. Journal of Power Sources. 2007. Vol.173(1). P.621-625.

[33] B.J. Monaghan, R. Nightingale, V. Daly, E. Fitzpatrick. Determination of the thermal histories of coke in a blast furnace through x-ray analysis. Ironmaking and Steelmaking. 2008. Vol.35. P.38-42.

[34] Ph. Ouzilleau, A.E. Gheribi, G. Eriksson, D.K. Lindberg, P. Chartrand. A size-dependent thermodynamic model for coke crystallites: The carbon-hydrogen system up to 2500K. Carbon. 2015. Vol.85. P.99-118.

[35] A.P. Karnaukhov. Adsorption. The texture of dispersed and porous materials. Novosibirsk: Science. Sib. RAS enterprise. 1999. 470p. (russian) 